\title{
VIVENDO, PARTILHANDO E APRENDENDO COM PAULO FREIRE
}

\author{
ANCASSUERD, Marli P. ${ }^{1}$ \\ É preciso uma aldeia para educar uma criança. \\ (provérbio africano)
}

Não vou me ater à cronologia para expor, aqui, observações e aprendizados. Assim, escrevo sobre algumas de minhas andanças em África (década dos 80), vinculadas ao trabalho político-pedagógico para formar alfabetizadores (de adultos).

Devo dizer que, nos anos de 1980, integrei sob a coordenação de Paulo Freire a equipe do Instituto de Ação Cultural ${ }^{2}$ (IDAC) responsável por projetos de alfabetização em países africanos recém libertos do colonialismo português. No meu caso particular, atuei em São Tomé e Príncipe e Cabo Verde. Como parte de nossas atribuições, destaca-se: elaborar materiais, formar alfabetizadores, produzir relatórios e atuar em atividades nas ilhas...

As lembranças estão vivas na minha memória e no meu corpo! Lembranças que me remetem, por exemplo, às imensas dificuldades econômicas enfrentadas por esses países; os altos percentuais de analfabetismo, em especial em São Tomé e Príncipe; as questões de saúde que não dispunham de profissionais da área, dependentes quase na sua totalidade de colaboração externa; as lojas que exibiam as prateleiras vazias; a fome e as perdas dos filhos, tristemente relatadas quando das epidemias de sarampo, cuja vacinação nos aeroportos de lá se assemelhava aos meus tempos de infância: agulhas comuns desinfetadas num lúmem!

Nossas viagens tinham datas marcadas de saída do Brasil e passagem por Lisboa (vistos, a impressão dos materiais, livros, cartilhas ${ }^{3}$ ). Contudo, não tinham

\footnotetext{
${ }^{1}$ Pedagoga. Atuou no IDAC com a gestão de projetos e produção de materiais didáticos para alfabetização de adultos em Cabo Verde e São Tomé e Príncipe. Foi professora do Centro Universitário Fundação Santo André e é pesquisadora do Grupo de Estudos e Pesquisas em Educação de Jovens e Adultos (GEPEJA) da Faculdade de Educação da Unicamp.

${ }^{2}$ Compunham a equipe do IDAC: Paulo e Elza Freire, Miguel e Rosiska Darcy de Oliveira, Claudius Ceccon, a quem se juntou mais tarde Marcos Arruda. Marli Ancassuerd, Kimiko e Marilena Nakano também chegaram mais tarde. A equipe correu mundo e participou de experiências educativas nos contextos sócio-culturais mais diversos, desde a alfabetização de adultos em países africanos até a ação cultural do movimento feminista europeu. Consultar, por exemplo: FREIRE [et. al.] (1980); FREIRE (1992); CECCON [et. al.] (1991) e SPIGOLON (2014).

${ }^{3}$ São Tomé e Príncipe estava recebendo o seu primeiro equipamento para impressão, uma doação da RDA (República Democrática Alemã) quando o projeto foi encerrado.
} 
DOI: 10.12957/e-mosaicos.2017. 31896

data marcada de chegada. Viagens, com itinerários que iam de Angola em guerra e o aeroporto de Luanda, deteriorado, onde nada havia para comer e beber. Vez ou outra uma ratazana passeava pelos salões, até as paisagens das janelas, quando os guardas cubanos permitiam, o rio e as matas. A natureza, linda, seguia o seu curso! Iam de São Tomé e Príncipe, que ao contrário de Cabo Verde, na cidade da Praia, pousávamos num aeroporto de pistas curtas. Às vezes, as tempestades nos dirigiam para a Costa do Marfim, longas esperas na retomada da viagem.

Bem, tudo valia a pena! E um detalhe que vale a pena: Professor Paulo Freire já retornara ao Brasil e era sempre lembrado por todos os funcionários das alfândegas e das embaixadas daqueles países e em Lisboa. Toda vez que lá chegávamos a primeira coisa que faziam era sempre nos pedir notícias do Professor Paulo Freire.

Como ampliei o meu olhar e meu conhecimento sobre os processos de dominação/exploração das nações africanas! Dizíamos: - Foram definidas com a régua e conhecíamos um pouco, hoje posso afirmar, das lutas de libertação desses povos, suas lideranças e combatentes.

O trabalho em África e o aprofundamento das propostas Freirianas permitiram o desvelamento dessas "imagens", ir para além de uma história factual e conhecer muito mais sobre as pessoas, os territórios e a produção das culturas. Aprendi com Paulo Freire a olhar os oprimidos, as ações dos opressores e suas estratégias de dominação, a natureza das diferentes comunidades (não só o aluno) e suas relações/ações na construção de uma sociedade mais justa. Aprendi a olhar, mais criticamente, as regras do jogo da internacionalização do capital e seus efeitos predatórios em África. Enfim, a construção dos modernos estados, também nos territórios africanos.

Devo ainda, mencionar que esse viver, partilhar e aprender, com Paulo Freire, com a equipe do IDAC e com os "camaradas" de Cabo Verde e São Tomé e Príncipe, foi uma oportunidade histórica na minha formação e atuação docente. Oportunidade que me estimulou a conhecer a riqueza da realidade africana, sua literatura, para além dos textos e poemas das lideranças nas lutas contra a dominação portuguesa e dos intelectuais/historiadores africanos. Fazendo uma transposição pelo tempo, uma boa e bela surpresa para quem lia somente Mia Couto e ouvia Cesárea Évora!

Ainda, mantenho contato com colaboradores de agora e de outrora naqueles países por onde andei, trabalhei, me envolvi. Quantas mudanças e permanências! Praia, muito linda, cresceu e reconhece a problemática juvenil; São Tomé e Príncipe, com muitas dificuldades econômicas, porém, com um decréscimo notável do analfabetismo; a saúde contando com a colaboração de universidade brasileiras. Seguem os processos neocolonialistas. Contudo, foi bom saber das levas de jovens que chegam às universidades!

Revisitando tais percursos de minha atuação e militância político-pedagógica, reconheço que segue sendo atual "uma questão de visão de mundo: qual? Diferente do que antes possuía?" (ANCASSUERD, 2008, p. 69). É perceptível a influência, 
DOI: $10.12957 /$ e-mosaicos.2017. 31896

dialógica e dialética, dessas experiências nas mudanças de visão do mundo, do outro e de mim.

"A esperanças é africana" e Freiriana. Que o sentir, pensar, fazer sejam "esperançar".

\section{REFERÊNCIAS BIBLIOGRÁFICAS:}

ANCASSUERD, Marli P. Pedagogia da Memória: registros históricos e testemunhos em defesa da FAFIL e do projeto de construção do curso de formação de professores na Fundação Santo André. São Paulo: Porto de Ideias, 2008.

CECCON, Claudius \& OLIVEIRA, Rosiska Darcy de; OLIVEIRA, Miguel Darcy de. $A$ vida na escola e a escola na vida. Petrópolis: Editora Vozes em co-edição IDAC, 1991.

FREIRE, Paulo. Pedagogia da Esperança: um reencontro com a Pedagogia do Oprimido. Rio de Janeiro: Paz e Terra, 1992.

\& OLIVEIRA, Rosiska Darcy de; OLIVEIRA, Miguel Darcy de; CECCON, Claudius. Vivendo e aprendendo: experiências do IDAC em educação popular. São Paulo: Livraria Brasiliense Editora S.A., 1980.

SPIGOLON, Nima I. As noites da ditadura e os dias de utopia - o exílio, a educação e os percursos de Elza Freire nos anos de 1964 a 1979. Tese (Doutorado). Universidade Estadual de Campinas, 2014. 